Ivica Zvonar

\title{
KORESPONDENCIJA IZMEĐU JOSIPA JURJA STROSSMAYERA I IVANA KOSTRENČIĆA U ARHIVU HRVATSKE AKADEMIJE ZNANOSTI I UMJETNOSTI
}

\author{
Ivica Zvonar \\ Odsjek za povijesne znanosti \\ ZPDZ HAZU \\ Zagreb
}

\author{
UDK 929Strossmayer, J. J. \\ 929Kostrenčić, I. \\ 94(497.5)"18"(044.2) \\ Prethodno priopćenje \\ Primljeno: 15.6.2016. \\ Prihvaćeno: 14.12.2016. \\ DOI: http://doi.org/10.21857/yq32ohqgq9
}

\begin{abstract}
U Arhivu Hrvatske akademije znanosti i umjetnosti u Zagrebu u fondu "Ivan Kostrenčić, Korespondencija, Josip Juraj Strossmayer" sačuvano je 16 pisama te jedna bilješka koje je biskup Josip Juraj Strossmayera u razdoblju od 1869. do 1899. iz Đakova uputio istaknutom hrvatskom sveučilišnom knjižničaru i kulturnom djelatniku Ivanu Kostrenčiću. Također, u Akademijinu arhivu u Strossmayerovoj ostavštini u dijelu fonda "Korespondencija, Pisma Strossmayeru, Ivan Kostrenčić" sačuvano je 16 pisama koja je Ivan Kostrenčić uputio Strossmayeru u razdoblju od 1871. do 1888. godine. Autor u radu u osnovnim crtama donosi podatke i kratku analizu raznovrsnih tema spomenutih u korespondenciji biskupa J. J. Strossmayera i I. Kostrenčića.

Ključne riječi: Josip Juraj Strossmayer, Ivan Kostrenčić, korespondencija, hrvatska povijest 19. st., politička povijest, kulturna povijest
\end{abstract}

\section{Uvod}

Josip Juraj Strossmayer i Ivan Kostrenčić pripadaju među istaknute i zaslužne osobe koje su u hrvatskom znanstvenom, crkvenom, kulturnom i političkom životu u svojem vremenu ostavili zapaženi trag. U fondu "Ivan Kostrenčić, Korespondencija, Josip Juraj Strossmayer", koji se nalazi u Arhivu Hrvatske akademije, sačuvano je ukupno 16 pisama i jedna bilješka koje mu je uputio biskup Strossmayer. ${ }^{1}$

Arhiv Hrvatske akademije znanosti i umjetnosti, fond: Ivan Kostrenčić, Korespondencija, Josip Juraj Strossmayer, sign.: XV-40 / br. 1-17. (dalje: AHAZU, Strossmayer - Kostrenčić). 
Ivica Zvonar: Korespondencija između Josipa Jurja Strossmayera i Ivana Kostrenčića...

Zb. Odsjeka povij. znan. Zavoda povij. druš. znan. Hrvat. akad. znan. umjet., 34 (2016), str. 197-211

Jedno pismo je iz 1899., dok za jedno ne možemo utvrditi vrijeme i mjesto nastanka. Ostala korespondencija obuhvaća razdoblje od 1869. do 1874. godine. Ta pisma svjedoče o životu i radu našeg istaknutog sveučilišnog knjižničara i kulturnog djelatnika Ivana Kostrenčića, ${ }^{2}$ te njegovoj zauzetosti i spremnosti da na razne načine pomogne Strossmayeru ${ }^{3}$ i drugim zemljacima na kulturnom, znanstvenom i političkom

2 Ivan Kostrenčić, hrvatski sveučilišni knjižničar (Crikvenica, 1844. - Crikvenica, 1924.). Školovanje je započeo u rodnoj Crikvenici, te nastavio u Rijeci i Senju. Bogosloviju je završio u Budimpešti (1866.), a povijest i slavistiku u Beču (1868.). Od 1868. do 1875. radio je kao knjižničar u Dvorskoj knjižnici u Beču. Pored toga, bio je docent za hrvatski jezik na "kk. Grenz-Verwaltungs-Curse"(1869.-1871.) i učitelj hrvatskog jezika na Terezijanskoj akademiji u Beču (1869.-1875.), a bavio se još prevođenjem i književnim radom. Od 1875. do 1911. djeluje kao prvi ravnatelj Kraljevske sveučilišne knjižnice u Zagrebu. Tijekom tog razdoblja Kraljevska sveučilišna knjižnica u Zagrebu počela je, po uzoru na njemačke znanstvene knjižnice, razvijati dvojnu funkciju (nacionalnu i sveučilišnu) svojega poslovanja. Kostrenčić se uporno borio za dignitet knjižničarske struke, nastojao je izgrađivati fond u svrhu potpore znanstvenom istraživanju i odvijanju sveučilišne nastave, a bio je uključen i u izradu planova za izgradnju nove zgrade knjižnice na Marulićevu trgu u Zagrebu. Osim toga, Kostrenčić se nakon dolaska u Zagreb aktivno uključio u kulturni život Hrvatske te je 1877. godine postao tajnik i blagajnik Matice hrvatske, a radio je u Matici i kao cenzor. Za detaljnije podatke o Kostrenčićevu životu i djelovanju usp. Dora Sečić, Ivan Kostrenčić: proi hrvatski sveučilišni bibliotekar = der erste Kroatischer Universitätsbibliothekar = first Croatian university librarian, Lokve, 2000., Ista, Kraljevska sveučilišna knjižnica u Zagrebu: razvoj $i$ djelovanje srednjoeuropske knjižnice od 1874. do 1918., Lokve, 2007. Također, o raznim aspektima Kostrenčićeva života i rada usp. Ivica Zvonar, Prilog poznavanju njemačkog knjižničarstva i doprinos Ivana Kostrenčića razvoju hrvatskog knjižničarstva u 19. i početkom 20. stoljeća, Časopis za suvremenu povijest, god. 33, br. 3, Zagreb 2001., str. 747-778; Isti, Nastojanja Ivana Kostrenčića oko poboljšanja statusa knjižničara u Sveučilišnoj knjižnici u Zagrebu krajem 19. i početkom 20. stoljeća, Zbornik Odsjeka za povijesne znanosti Zavoda za društvene i povijesne znanosti HAZU (dalje: Zbornik OPZ), sv. 20, Zagreb 2002., str. 269-286.; Isti, Pet pisama Ivana Kostrenčića Franji pl. Markoviću, Zbornik OPZ, sv. 21, Zagreb 2003., str. 267-275; Isti, Dnevnički zapisi Ivana Kostrenčića o reviziji Hrvatsko-ugarske nagodbe (1871.1782.) iz Arhiva Hrvatske akademije znanosti i umjetnosti, Zbornik OPZ, sv. 23, Zagreb 2005., str. 259271; Isti, Prilog poznavanju života i rada Ivana Kostrenčića u Beču: 1868.-1875., Zbornik OPZ, sv. 24, Zagreb 2006., str. 187-198; Isti, Rukopisna ostavština Ivana Kostrenčića u Arhivu Hrvatske akademije znanosti i umjetnosti $=$ The Ivan Kostrenčić Papers in the Archives of the Croatian Academy of Sciences and Arts in Zagreb, u: 400. obljetnica Nacionalne i sveučilišne knjižnice u Zagrebu [Elektronička građa] : zbornik radova sa znanstveno-stručnog skupa, Zagreb, 9.-11. svibnja 2007. = 400th anniversary of the National and University Library in Zagreb: proceedings of the scientific conference, Zagreb, 9th-11th May 2007, Zagreb 2007., str. 51-65; Isti, Pisma Franje Račkoga upućena Ivanu Kostrenčiću u razdoblju od 1868. do 1875. Zbornik OPZ, sv. 25, Zagreb 2007., str. 203-224; Isti, Korespondencija između Ivana Kostrenčića i Metela Ožegovića u Arhivu Hrvatske akademije znanosti i umjetnosti u Zagrebu, Cris: časopis Povijesnog društva Križevci, sv. 14, br. 1, Križevci 2011., str. 107-117.

3 Josip Juraj Strossmayer, đakovački biskup i hrvatski političar (Osijek, 1815. - Đakovo, 1905). Nakon završena Sjemenište pohađao u Đakovu, a teologiju studirao u Pešti, gdje je 1834. doktorirao filozofiju. Zaređen je 1838. godine. Na Augustineumu u Beču 1842. doktorirao je teologiju. Obnašao je službu profesora u đakovačkom sjemeništu, a obavljao je i službu dvorskoga kapelana i jednog od trojice ravnatelja Augustineuma u Beču. Ujesen 1849. imenovan je srijemsko-bosanskim biskupom, a ustoličen 1850. godine. Djelovao je i na političkom polju, pa je tako od 1860. do 1873. bio istaknuti prvak Narodne stranke, tada vodeće snage hrvatskog nacionalnog pokreta. Bio je virilni zastupnik u Hrvatskom saboru te veliki župan Virovitičke županije. Nakon sklapanja Hrvatsko-ugarske nagodbe (1868.), revizije Nagodbe (1873.) i popuštanja narodnjaka pred mađarskim zahtjevima, 1873. nezadovoljan situacijom, povlači se iz politike. No, 1880. pristao je uz Neodvisnu narodnu stranku, ali se 1894. posve povlači se iz političkog života. Zajedno s Franjom Račkim zastupao je južnoslavensku ideju s ciljem osnivanja savezne države Južnih Slavena, uz potporu ostalih slavenskih naroda, kao protuteže Nijemcima, Mađarima i Talijanima, a nakon Berlinskoga kongresa 1878., zastupa ideju federativne, pa čak i trijalistički uređene Austro-Ugarske Monarhije. Snažno je utjecao na suvremeni crkveni i vjerski život. 
Ivica Zvonar: Korespondencija između Josipa Jurja Strossmayera i Ivana Kostrenčića...

Zb. Odsjeka povij. znan. Zavoda povij. druš. znan. Hrvat. akad. znan. umjet., 34 (2016), str. 197-211

planu. Također, pisma donose sažete Strossmayerove komentare o pojedinim političkim prilikama u hrvatskom društvu i Austro-Ugarskoj Monarhiji, ali potvrđuju i Kostrenčićevo zanimanje za politička zbivanja na hrvatskom prostoru početkom sedamdesetih godina 19. stoljeća.

U ostavštini biskupa Josipa Jurja Strossmayera, koja se čuva u Arhivu Hrvatske akademije znanosti i umjetnosti u Zagrebu, nalazi se u dijelu fonda "Korespondencija, Pisma Strossmayeru, Ivan Kostrenčić" 16 pisama koje je Ivan Kostrenčić uputio Strossmayeru u razdoblju od svibnja 1871. do studenog 1888. godine. ${ }^{4}$ Najveći dio pisama obuhvaća razdoblje od 1871. do 1875 . godine, i ponajprije daje uvid u pojedine segmente kulturnog i političkog djelovanja Kostrenčića i Strossmayera. Pored toga, treba reći da su u Strossmayerovoj ostavštini još sačuvane dvije Kostrenčićeve posjetnice, ${ }^{5} \mathrm{dvije}$ telegrafske čestitke iz prve polovine devedesetih godina 19 . stoljeća, i tri brzojavne čestitke koje su biskupu Strossmayeru uputili supružnici Ivan i Zlata Kostrenčić prigodom proslave 40. i 50. obljetnice njegove biskupske službe, odnosno 60 . godišnjice misništva. ${ }^{6}$

Zalagao se za međusobno razumijevanje i pomirenje katolika, pravoslavaca i protestanata, a posebice je bilo zapaženo njegovo djelovanje na zasjedanju Prvoga vatikanskoga koncila (8. XII. 1869 - 18. VII. 1870). Također, istaknuo se i kao mecena na kulturno-prosvjetnom planu. Novčano je pomagao mnoge pojedince, Zavod sv. Jeronima u Rimu, stipendirao je bosanske franjevce, pomogao je osnivanje Više gimnazije u Osijeku, osnivanje Kongregacije Svetih anđela čuvara sestara dominikanki i gradnju njihova samostana $u$ Korčuli, tiskanje pojedinih hrvatskih novina, Maticu dalmatinsku, Maticu hrvatsku, Maticu srpsku i Maticu slovensku, te osnivanje tiskare na Cetinju. Godine 1860. darovao je 50000 forinti za osnutak Jugoslavenske akademije znanosti i umjetnosti u Zagrebu. Također, pomogao je gradnju Akademijine palače, osnutak njezina Arhiva i utemeljenje galerije kojoj je darovao svoju privatnu zbirku slika, a novčano je podupirao tiskanje najvažnijih Akademijinih izdanja (Rad JAZU, Ljetopis JAZU, Starine i dr.). Godine 1866. darovao je 50000 forinti za osnivanje modernoga sveučilišta u Zagrebu, a iste godine započeo je izgradnju đakovačke katedrale. Ukratko o Strossmayeru usp. "Strossmayer, Josip Juraj", Hrvatska enciklopedija, sv. 10, Zagreb 2008., str. 297-298. Na stranicama raznih znanstvenih i stručnih periodičkih publikacija s područja humanističkih znanosti postoji niz vrijednih radova o Strossmayeru. No, na ovome mjestu upućujemo tek na nekoliko monografija koje su o Strossmayerovu djelovanju napisane u novije vrijeme od strane pojedinih povjesničara - npr. usp. Vladimir Košćak, Josip Juraj Strossmayer, političar i mecena, Osijek 1990., William Brooks Tomljanovich, Biskup Josip Juraj Strossmayer: Nacionalizam i moderni katolicizam u Hroatskoj, Zagreb 2001., Medunarodni znanstveni skup Josip Juraj Strossmayer, Zagreb, 19. svibnja 2005. [i] Đakovo, 20. svibnja 2005.: povodom 190. obljetnice rođenja i 100. obljetnice smrti : zbornik radova, ur. Franjo Šanjek, Zagreb, 2006. Disertaciju o Strossmayeru je 2005. obranio crkveni povjesničar Slavko Slišković. O tome usp. Slavko Slišković, Strossmayerova vanjska politika, djelovanje i recepcija, neobjavljena doktorska disertacija, Zagreb 2005. Pored toga, od najnovijih izdanja Strossmayerovih djela potrebno je spomenuti naslove: Josip Juraj Strosssmayer, Izabrani književni i politički spisi, Zagreb 2005., koje je priredio akad. Dubravko Jelčić, i Josip Juraj Strosssmayer, Sve za vjeru i domovinu: IV. svezak: Prigodne okružnice i propovijedi te značajniji govori i osvrti (1850. - 1905.), Đakovo 2015., koje su priredili mons. Marin Srakić i Ankica Landeka, uz uredničku potporu mons. Vladimira Dugalića.

4 Arhiv Hrvatske akademije znanosti i umjetnosti, fond: Ostavština Josipa Jurja Strossmayera, Korespondencija, Pisma Strossmayeru, Ivan Kostrenčić, sign.: XI A / Kost. I., br. 1-16. (dalje: AHAZU, Kostrenčić - Strossmayer).

5 Arhiv Hrvatske akademije znanosti i umjetnosti, fond: Ostavština Josipa Jurja Strossmayera, sign.: XI C. Posjetnice, Ivan Kostrenčić. Na posjetnicama nema oznake mjesta i datuma, kao ni nikakvih pisanih poruka.

6 Arhiv Hrvatske akademije znanosti i umjetnosti, fond: Ostavština Josipa Jurja Strossmayera, sign.: XI E. Telegrafske čestitke i pozdravi, Brzojavne čestitke / Ivan i Zlata Kostrenčić. 
Ivica Zvonar: Korespondencija između Josipa Jurja Strossmayera i Ivana Kostrenčića...

Zb. Odsjeka povij. znan. Zavoda povij. druš. znan. Hrvat. akad. znan. umjet., 34 (2016), str. 197-211

U dosadašnjoj je historiografiji na važnost korespondencije između Strossmayera i Kostrenčića, i potrebu njene daljnje analize s obzirom na političku i kulturnu dimenziju, tek kratko s nekoliko rečenica još prije više od pola stoljeća upozorio Vladimir Košćak.7

\section{Korespondencija Strossmayer - Kostrenčić: kratki osvrt}

Korespondencija između Josipa Jurja Strossmayera i Ivana Kostrenčića najvećim dijelom obuhvaća, kako smo u uvodu napomenuli, razdoblje od 1869. do 1874. godine, dok je tek jedno pismo iz 1899. godine. Dvanaest pisama ne sadrži mjesto nastanka, četiri su poslana iz Đakova, a jedno je bez mjesta i nadnevka. Rukopis pisama je relativno čitljiv, a pisma su opsegom različita - od nekoliko rečenica napisanih na pola stranice, pa do četiri stranice teksta. U svezi formata stranice treba reći da se obično radi o listu veličine otprilike današnjeg A4 formata, koji je potom bio presavijen, pa bi tako tvorio četiri stranice. No, s obzirom na Strossmayerovu grafiju, može se reći da su i pisma od četiri stranice zapravo kratka. Također, treba reći da nije uvijek iz pisama jasno što je sve Kostrenčić slao Strossmayeru, odnosno obavljao po njegovu nalogu. ${ }^{8}$

U pismima se Strossmayer obraća Kostrenčiću s poštovanjem i kao prijatelju (npr. "Dragi moj priatelju”, "Vele cjenjeni priatelju”, itd.), te mu u mnogim prigodama od srca zahvaljuje na raznim uslugama. Sa sigurnošću možemo ustvrditi da je Strossmayer cijenio Kostrenčićev rad, i bio mu je, kako sam piše, “za sve, što ste za me i za narod učinili zahvalan". ${ }^{9}$ Tako primjerice, Strosssmayer zahvaljuje Kostrenčiću na poslanim knjigama, te ga hvali za to "što nam opisaste život vrloga našega starine" (Mirka Ožegovića, op. I. Z.). ${ }^{10}$ Osim knjiga, Kostrenčić je po potrebi za Strossmayera tražio razne spise i gradivo iz arhiva. ${ }^{11}$

U raznim je prigodama Kostrenčić prenosio Strossmayerove pozdrave, poruke i pisma njegovim prijateljima i suradnicima u Beču - npr. političaru i dobrotvoru

7 O tome usp. Vladimir Košćak, Strossmayerova ostavština u Arhivu JAZU, Historijski zbornik (dalje: HZ), sv. 11-12, Zagreb 1958.-1959., str. 361, 368-369; Isti, Strossmayerova ostavština - ostali fondovi, HZ, sv. 13, Zagreb 1960., str. 269-270. Nije mi poznato da su u međuvremenu do sada bila negdje korištena pisma iz korespondencije između J. J. Strossmayera i I. Kostrenčića.

8 AHAZU, Strossmayer - Kostrenčić, br. 2. Pismo koje je J. J. Strossmayer 7. VIII. 1871. (bez mjesta) uputio I. Kostrenčiću. Strossmayer zahvaljuje Kostrenčiću što mu je poslao "njeke stvari koje trebamo", ali nije jasno o čemu se točno radi. Također, usp. i AHAZU, Strossmayer - Kostrenčić, br. 12. Pismo koje je J. J. Strossmayer 26. VI. 1873. (bez mjesta) uputio I. Kostrenčiću.

9 AHAZU, Strossmayer - Kostrenčić, br. 2. Pismo koje je J. J. Strossmayer 7. VIII. 1871. (bez mjesta) uputio I. Kostrenčiću.

10 AHAZU, Strossmayer - Kostrenčić, br. 1. Pismo koje je J. J. Strossmayer 3. IV. 1869. (bez mjesta) uputio I. Kostrenčiću. Vjerojatno se radi o djelu Uspomena Mirka bar. Ožegovića Barlabaševačkoga biskupa senjskoga i modruškoga ili krbavskoga, koje je I. Kostrenčić objavio u Beču 1869.

11 AHAZU, Strossmayer - Kostrenčić, br. 4. Pismo koje je J. J. Strossmayer 10. X. 1871. (Đakovo) uputio I. Kostrenčiću. 
Ivica Zvonar: Korespondencija između Josipa Jurja Strossmayera i Ivana Kostrenčića... Zb. Odsjeka povij. znan. Zavoda povij. druš. znan. Hrvat. akad. znan. umjet., 34 (2016), str. 197-211

Metelu Ožegoviću, ${ }^{12}$ generalu Petru Preradoviću, ${ }^{13}$ jezikoslovcu Francu Miklošiću ${ }^{14}$ i drugima. Pregledom korespondencije između Strossmayera i Kostrenčića razvidno je da se Strossmayer kroz svoja pisma povremeno osvrće na političke prilike u Austro-Ugarskoj Monarhiji, i na djelovanje dijela istaknutih hrvatskih političara iz razdoblja sedamdesetih godina 19. stoljeća (npr. Mirko Šuhaj, Matija Mrazović, Ivan Danilo, Đuro Vojnović i dr.). ${ }^{15}$ Tako pisma ponajprije sadrže Strossmayerove komentare o političkim prilikama u Monarhiji nakon Nagodbe. U pismima Kostrenčiću on se nije libio iznijeti negativno mišljenje o pojedinim tadašnjim istaknutim političarima (npr. predsjedniku Vlade Friedrichu Ferdinandu Beustu). ${ }^{16}$ Strossmayer je bio razočaran dalmatinskim političarima i njihovim držanjem u Carevinskom vijeću u Beču, ${ }^{17}$ pa je zato u pismu od 12. travnja 1873. zamolio Kostrenčića da prati njihove reakcije na političkom planu. ${ }^{18} \mathrm{Iz}$ Stossmayerovih pisama možemo vidjeti i stanoviti interes Ivana Kostrenčića za politički život hrvatskog naroda (npr. njegovi istupi u Obzoru, osvrti na financijska pitanja Nagodbe) početkom sedamdesetih godina 19. stoljeća. Zato Strossmayer upućuje Kostrenčića da na isti način u novinama piše i o pitanju hrvatske granice. Upućuje ga da o toj problematici porazgovara s relevantnim sugovornicima, te kao iskusan političar napominje: "Sva naša stvar zavisi o naših financia". ${ }^{19}$

U nekoliko Strossmayerovih pisama spominju se i određeni poslovi u svezi katedrale u Đakovu. Naime, on je posredovanjem Kostrenčića nastojao u Beču doći do pojedinih osoba (npr. arhitekt Friedrich Schmidt i slikar Johann Friedrich Overbeck)

12 AHAZU, Strossmayer - Kostrenčić, br. 4. Pismo koje je J. J. Strossmayer 10. X. 1871. (Đakovo) uputio I. Kostrenčiću ; br. 9. Pismo koje je J. J. Strossmayer 25. X. 1872. (bez mjesta) uputio I. Kostrenčícu; br. 13. Pismo koje je J. J. Strossmayer 19. VII. 1873. (bez mjesta) uputio I. Kostrenčiću; br. 15. Pismo koje je J. J. Strossmayer, blagdan Duhova, 1874. (bez mjesta) uputio I. Kostrenčiću.

13 AHAZU, Strossmayer - Kostrenčić, br. 7. Pismo koje je J. J. Strossmayer 7. VII. 1872. (bez mjesta) uputio I. Kostrenčiću; AHAZU, Strossmayer - Kostrenčić, br. 8. Pismo koje je J. J. Strossmayer 23. VII. 1872. (bez mjesta) uputio I. Kostrenčiću.

14 AHAZU, Strossmayer - Kostrenčić, br. 3. Pismo koje je J. J. Strossmayer 15. IX. 1871. (bez mjesta) uputio I. Kostrenčiću; br. 15. Pismo koje je J. J. Strossmayer, blagdan Duhova, 1874. (bez mjesta) uputio I. Kostrenčiću.

15 AHAZU, Strossmayer - Kostrenčić, br. 11. Pismo koje je J. J. Strossmayer 12. IV. 1873. (bez mjesta) uputio I. Kostrenčiću.

16 AHAZU, Strossmayer - Kostrenčić, br. 5. Pismo koje je J. J. Strossmayer 11. XI. 1871. (bez mjesta) uputio I. Kostrenčiću. Za osnovni pregled zbivanja na političkom polju krajem šezdesetih i početkom sedamdesetih godina 19. stoljeća na hrvatskom prostoru usp. Jaroslav Šidak et al., Povijest hrvatskog naroda g. 1860-1914, Zagreb 1968.; Ivo Perić, Hrvatska državotvorna misao u XIX. i XX. stoljeću, Zagreb 2002 U hrvatskoj historiografiji, osim navedenih naslova, postoji niz drugih kvalitetnih knjiga i rasprava koje tematiziraju ovo razdoblje, pa je radi detaljnijeg uvida korisno pogledati literaturu na koju u svojim knjigama navode ovdje spomenuti autori.

17 AHAZU, Strossmayer - Kostrenčić, br. 10. Pismo koje je J. J. Strossmayer 15. III. 1873. (Đakovo) uputio I. Kostrenčiću, i AHAZU, Strossmayer - Kostrenčić, br. 11. Pismo koje je J. J. Strossmayer 12. IV. 1873. (bez mjesta) uputio I. Kostrenčiću.

18 AHAZU, Strossmayer - Kostrenčić, br. 11. Pismo koje je J. J. Strossmayer 12. IV. 1873. (bez mjesta) uputio I. Kostrenčiću.

19 AHAZU, Strossmayer - Kostrenčić, br. 8. Pismo koje je J. J. Strossmayer 23. VII. 1872. (bez mjesta) uputio I. Kostrenčiću. 
Ivica Zvonar: Korespondencija između Josipa Jurja Strossmayera i Ivana Kostrenčića...

Zb. Odsjeka povij. znan. Zavoda povij. druš. znan. Hrvat. akad. znan. umjet., 34 (2016), str. 197-211

radi uređenja katedrale..$^{20} \mathrm{U}$ tom je kontekstu Kostrenčić bio zadužen da kontaktira umjetnike (npr. slikari Franz Leo Ruben i Josip Voltolini) i trgovce glede izrade ili pak nabave raznih umjetnina. ${ }^{21}$ Zasigurno je bio spretan bar u dijelu tih poslova, jer $\mathrm{mu}$ je 1874. godine Strossmayer pismom zahvalio za uspješno obavljen posao oko nabave misnog posuđa. ${ }^{22}$

Povremeno je Kostrenčić činio Strossmayeru i neke usluge privatne naravi. Tako ga je Strossmayer zamolio da potraži guvernantu za njegovu sestru Magdalenu, ${ }^{23}$ da mu ponekad pomogne oko smještaja prigodom dolaska u Beč ${ }^{24}$ ili pak da pribavi staklo na okvire za pojedine slike koje posjeduje. ${ }^{25} \mathrm{U}$ sferu osobnoga spada i telegram od 19. ožujka 1872., odnosno kratko pismo na pola stranice od 21. ožujka 1899., koje je Strossmayer napisao u Đakovu, gdje se zahvaljuje Kostrenčiću i njegovoj supruzi na čestitkama povodom imendana. ${ }^{26}$ Pored komunikacije pismenim putem, Strossmayer se prigodom svojih dolazaka u Beč, nastojao nakratko i susresti s Kostrenčićem. ${ }^{27}$

\section{Korespondencija Kostrenčić - Strossmayer: kratki osvrt}

Korespondencija između Ivana Kostrenčića i Josipa Jurja Strossmayera obuhvaća, kako je već prije spomenuto, vrijeme od 1871. do 1888. godine. Trinaest pisama je iz razdoblja 1871. do 1875., dva su pisma bez nadnevka, a jedno je iz 1888. godine. Deset pisama Kostrenčić je Strossmayeru uputio iz Beča, četiri pisma su bez oznake mjesta, a po jedno je bilo poslano iz Zagreba i Osijeka. Rukopis pisama je uredan i čitljiv, a pisma su opsegom različita - od nekoliko rečenica napisanih na pola stranice, pa do sedam stranica teksta. Glede formata stranice treba reći da se obično radi o listu veličine otprilike današnjeg formata A4, koji je potom bio presavijen, pa bi

${ }^{20}$ AHAZU, Strossmayer - Kostrenčić, br. 9. Pismo koje je J. J. Strossmayer 25. XI. 1872. (bez mjesta) uputio I. Kostrenčiću.

21 AHAZU, Strossmayer - Kostrenčić, br. 10. Pismo koje je J. J. Strossmayer 15. III. 1873. (Đakovo) uputio I. Kostrenčiću; AHAZU, Strossmayer - Kostrenčić, br. 13. Pismo koje je J. J. Strossmayer 19. VII. 1873. (bez mjesta) uputio I. Kostrenčiću; br. 14. Pismo koje je J. J. Strossmayer 28. IV. 1874. (bez mjesta) uputio I. Kostrenčiću ; br. 15. Pismo koje je J. J. Strossmayer, blagdan Duhova, 1874. (bez mjesta) uputio I. Kostrenčiću. Na informaciji o J. Voltoliniju zahvaljujem kolegici dr. sc. Ljerki Dulibić iz Strossmayerove galerije starih majstora HAZU.

22 AHAZU, Strossmayer - Kostrenčić, br. 15. Pismo koje je J. J. Strossmayer, blagdan Duhova, 1874. (bez mjesta) uputio I. Kostrenčiću.

23 AHAZU, Strossmayer - Kostrenčić, br. 7. Pismo koje je J. J. Strossmayer 7. VII. 1872. (bez mjesta) uputio I. Kostrenčiću; br. 7a. Pismo Magdalene Unukić 23.7.1872. (Bohitsch).

24 AHAZU, Strossmayer - Kostrenčić, br. 10. Pismo koje je J. J. Strossmayer 15. III. 1873. (Đakovo) uputio I. Kostrenčiću; AHAZU, Strossmayer - Kostrenčić, br. 11. Pismo koje je J. J. Strossmayer 12. IV. 1873. (bez mjesta) uputio I. Kostrenčiću.

25 AHAZU, Strossmayer - Kostrenčić, br. 17. Pismo koje je J. J. Strossmayer (bez mjesta i datuma) uputio I. Kostrenčiću.

26 AHAZU, Strossmayer - Kostrenčić, br. 6. Pismo koje je J. J. Strossmayer 19. III. 1872. (Đakovo) uputio I. Kostrenčiću, i AHAZU, Strossmayer - Kostrenčić, br. 16. Pismo koje je J. J. Strossmayer 21. III. 1899. (Đakovo) uputio I. Kostrenčiću.

${ }^{27}$ AHAZU, Strossmayer - Kostrenčić, br. 2. Pismo koje je J. J. Strossmayer 7. VIII. 1871. (bez mjesta) uputio I. Kostrenčiću. 
Ivica Zvonar: Korespondencija između Josipa Jurja Strossmayera i Ivana Kostrenčića... Zb. Odsjeka povij. znan. Zavoda povij. druš. znan. Hrvat. akad. znan. umjet., 34 (2016), str. 197-211

tako tvorio četiri stranice, a tek dva pisma su formatom nešto manja od A4. Samo iz jednoga pisma napisanoga na jednoj stranici na njemačkom jeziku, bez mjesta i datuma, a koje je sačuvano samo fragmentarno, ostaje nejasno što je točno predmet korespondencije. ${ }^{28}$ Kostrenčić često svoja pisma biskupu Strossmayeru završava kao "Vaš pokorni", "odani i na službu pripravni" i tomu slično.

Kostrenčićevo pismo od 6. svibnja, bez točne godine (možda 1874., ali svakako iz vremena njegova života u Beču), pokazuje opseg poslova koji je on obavljao u Beču za potrebe i po nalogu biskupa Strossmayera, a koje smo već u određenom mjeri uočili na temelju uvida u korespondenciju Strossmayer - Kostrenčić. Tako je Kostrenčić često prenosio Strossmayerova pisma i poruke određenim osobama (npr. u kontaktima s Josipom Jirečekom, Mihovilom Pavlinovićem, Mihom Klaićem, Metelom Ožegovićem, Lovrom Montijem, Ignjatom Wurmom, Kostom Vojnovićem i drugima), te prosljeđivao njihove odgovore biskupu. Provjeravao je u arhivima, ministarstvima i drugim tijelima podatke, i slao biskupu izvatke iz određenih dokumenata (npr. glede financijske nagodbe, potraga za nekim osobama, izvješća nuncija i dr.). Također, Kostrenčić je dijelom dogovarao kupovinu i preuzimanje umjetnina i predmeta, brinuo se za izradu okvira i stakala na slikama, te vodio brigu o njihovom transportu u Hrvatsku. Kontaktirao je pojedine izdavače za tiskanje raznih djela (npr. glede "izdanja Overbeckovih kartonah"), vodio je brigu oko izrade ili nabave kaleža, stolova, stolica, a u dijelu tih poslova mu je pomagao i Strossmayerov prijatelj kanonik Nikola Voršak. Sve to je Ivan Kostrenčić obavljao, pažljivo, strpljivo i obzirno, nastojeći da trošak poslova bude što manji, pa je zato često pri dogovoru zatražio predračun kako bi se mogao konzultirati sa Strossmayerom. ${ }^{29} \mathrm{O}$ pojedinim slikama koje su se pojavljivale na tržištu, Kostrenčić je u više navrata izvještavao Strossmayera. Primjerice, u pismu od 14. siječnja 1874. upućenom iz Beča piše mu o okolnostima pod kojima je iz Dubrovnika bila donesena na prodaju u Berlin slika za koju se pretpostavljalo da je pod Michelangelovom paskom naslikao talijanski slikar Marcello Venusti. ${ }^{30}$

Iz pisma od 12. lipnja 1874. upućenom iz Beča vidljivo je da je Kostrenčić za rješavanje određenih poslova (npr. nesuglasice sa slikarom F. L. Rubenom) koje mu je Strossmayer povjerio, angažirao nekog odvjetnika. Također, brinuo se i za restauraciju slika, preuzimao pošiljke s umjetninama iz Rima, te izvještavao biskupa o stanju prispjelih stvari. U određenim je situacijama Kostrenčić, kako se vidi iz korespondencija, svoje slobodno vrijeme čak podređivao poslovima koje je obavljao za biskupa. ${ }^{31}$ Opseg Kostrenčićevih poslova za potrebe Strossmayera pokazuje i njegovo pismo od 28. srpnja 1874., upućeno iz Beča, iz kojega je vidljivo da je Kostrenčić prema

28 AHAZU, Kostrenčić - Strossmayer, br. 16. Pismo koje je I. Kostrenčić (bez mjesta i datuma) uputio J. J. Strossmayeru.

29 AHAZU, Kostrenčić - Strossmayer, br. 5. Pismo koje je I. Kostrenčić 6. V. (1874.?) (Beč?) uputio J. J. Strossmayeru.

30 AHAZU, Kostrenčić - Strossmayer, 3. Pismo koje je I. Kostrenčić 14. I. 1874. (Beč) uputio J. J. Strossmayeru.

31 AHAZU, Kostrenčić - Strossmayer, br. 6. Pismo koje je I. Kostrenčić 12. VI. 1874. (Beč) uputio J. J. Strossmayeru. 
Ivica Zvonar: Korespondencija između Josipa Jurja Strossmayera i Ivana Kostrenčića...

Zb. Odsjeka povij. znan. Zavoda povij. druš. znan. Hrvat. akad. znan. umjet., 34 (2016), str. 197-211

Strossmayerovim naputcima posjećivao i konzultirao slikare, restauratore, procjenitelje i poznavatelje umjetničkih djela (npr. Karla Schelleina), kako bi od njih dobio određene informacije, prenio im Strossmayerove zahtjeve ili pak zastupao njegove interese..$^{32}$ Osim toga, po potrebi je Kostrenčić za Strossmayera preuzimao i poštu koje je stizala u Beč na biskupovo ime. ${ }^{33}$

Pismo koje je Kostrenčić napisao 20. srpnja 1874. u Beču zorno potvrđuje njegovu bliskost, veliko međusobno povjerenje i suradnju s obitelji Ožegović i biskupom Strossmayerom, kao i povezanost s obitelji Preradović. Na određeni je način Kostrenčić tijekom svojega boravka i rada u Beču sve njih povezivao - prenosio je pisma i poruke, posjećivao ih i družio se njima, te im često pomagao u obavljanju niza poslova i ostvarivanju kontakata. ${ }^{34}$

Dio pisama iz Kostrenčićeve korespondencije sa Strossmayerom tiče se u određenoj mjeri i njegovoga privatnoga života, te razvoja karijere knjižničara. Kroz ta se pisma "prelamaju" njegove prosudbe o domovini Hrvatskoj, statusu knjižničarske struke, kao i određene emotivne dileme. Tako primjerice, Kostrenčićevo pismo napisano 9. svibnja 1875. u Beču, na čak sedam stranica, koje je uputio Strossmayeru na nagovor Metela Ožegovića, tiče se samoga Kostrenčića i natječaja za mjesto knjižničara u Kraljevskoj sveučilišnoj knjižnici u Zagrebu. Tada piše Strosssmayeru da ga mnogi prijatelji nagovaraju da se natječe za to mjesto, ali da tome baš i nije sklon, i to iz više razloga - u Beču je u stručnom i materijalnom smislu zadovoljan, a u Zagrebu ne zna što ga sve može zateći, jer tu knjižničar nije izjednačen u statusu sa sveučilišnim profesorima, odnosno u podređenom je položaju. U tom kontekstu Kostrenčić napominje Strossmayeru da ga vuče želja Hrvatskom, jer ga je u dosadašnjem školovanju i radu vodila ljubav i nastojanje "da plodove ovoga truda moći ću možda jednom i svojoj domovini posvetiti". ${ }^{35}$ Posebice ističe da bi ga radovao povratak, jer "želja moja za zemljom hrvatskom je svagdanja i nikoga veselijega od mene, kad i ako uzmognem jednom stupiti u svoj dom i pozdraviti mile nam brežuljke i doline, poljubiti sveto tlo otaca naših i kazati: oj zemljo moja! Evo se vraćam u tvoje krilo,

32 AHAZU, Kostrenčić - Strossmayer, br. 7. Pismo koje je I. Kostrenčić 15. VI. 1874. (Beč?) uputio J. J Strossmayeru. ; AHAZU, Kostrenčić - Strossmayer, br. 9. Pismo koje je I. Kostrenčić 28. VII. 1874. (Beč) uputio J. J. Strossmayeru. Na korisnoj informaciji o djelovanju K. Schelleina zahvaljujem kolegici dr. sc. Ljerki Dulibić iz Strossmayerove galerije starih majstora HAZU. Detaljnije o Schelleinu usp. Ljerka Dulibić - Iva Pasini Tržec, Biskup Josip Juraj Strossmayer kao sakupljač umjetnina (radni naslov; knjiga u pripremi).

33 AHAZU, Kostrenčić - Strossmayer, br. 11. Pismo koje je I. Kostrenčić 28. VI. 1875. (Beč) uputio J. J. Strossmayeru.

34 AHAZU, Kostrenčić - Strossmayer, br. 8. Pismo koje je I. Kostrenčić 20. VII. 1874. (Beč) uputio J. J. Strossmayeru ; AHAZU, Kostrenčić - Strossmayer, br. 13. Pismo koje je I. Kostrenčić 16. VIII. 1875. (Beč) uputio J. J. Strossmayeru. Također, Kostrenčićevo pismo bez točnog nadnevka potvrđuje njegovu bliskost s Ožegovićima i Strossmayerom. Usp. AHAZU, Kostrenčić - Strossmayer, br. 15. Pismo koje je I. Kostrenčić (Osijek, bez datuma) uputio J. J. Strossmayeru.

35 AHAZU, Kostrenčić - Strossmayer, br. 10. Pismo koje je I. Kostrenčić 9. V. 1875. (Beč) uputio J. J. Strossmayeru. O problematici statusa knjižničara u Zagrebu i Kostrenčićevim nastojanjima za detaljnije objašnjenje usp. Zvonar, Nastojanja Ivana Kostrenčića oko poboljšanja statusa, str. 269-286; Isti, Prilog poznavanju života i rada Ivana Kostrenčića u Beču, str. 187-198. 
Ivica Zvonar: Korespondencija između Josipa Jurja Strossmayera i Ivana Kostrenčića...

Zb. Odsjeka povij. znan. Zavoda povij. druš. znan. Hrvat. akad. znan. umjet., 34 (2016), str. 197-211

da se u tudjinu nikad više nevratim!"”36 U svojoj zemlji, koju voli i poštuje, želi raditi vrijedno i pošteno, ali, kako naglašava, "sinekure ni nemolim ni neprimam, - al ni milosti!" 37 Ne bi želio da mu se, ukoliko se ne javi na natječaj, predbaci "pomanjkanje patriotizma, kao što se s ovom rieči u obće kod nas vele trguje".$^{38}$ Glede situacije oko mjesta sveučilišnog knjižničara u Zagrebu, Kostrenčić smatra da "nije položaj bibliotekara takav, da bi mogao uspješno djelovati, pošto nema nikakve garantije za njeku samostalnost proti svakim i svakakovim aspiracijam kojih ima u Zagrebu podosta, a bit će jih sve dosele, dok se neupute da mjesto bibliotekara nije sinekura". ${ }^{39}$ On naglašava da je za njega to "mjesto truda i muke, spreme za nauk i naobraženje, a u to ime bi bio moj zahtjev, da pošto se je sav statut universitetski uzeo iz Cislajtanije, da i u pogledu biblioteke se isti prisvoji i to i u pogledu djelokruga i vlasti i rad materijalna probitka". ${ }^{40}$ Sve drugo je u Hrvatskoj, napominje Kostrenčić, "izjednačeno universitetam cislajtanskim, samo biblioteku, kako naši ljudi misle sinekuru, mimoišli su i bacili njoj neku kost, da dodje kakav 'Pogledić'”'. ${ }^{41}$ Kostrenčić tvrdi da odlaskom iz Beča svakako gubi u materijalnom pogledu, "al ako nemogu pristojno u Zagrebu bitisati, to ni neću tamo da budem. Ovdje mogu kako tako živjeti, a tamo sam na ruglo!" ${ }^{22}$ U slučaju dolaska u Zagrebu, traži da bude "moralno i materijalno osiguran, da uzmognem po svojoj svesti i silah što bolje raditi". ${ }^{33}$ Izražava sumnju u ljude koji o tome u Zagrebu odlučuju, i smatra da njegovi nadređeni ne bi cijenili njegov rad, a sam ne želi biti "nakovalo", i zavisiti od tuđe milosti. ${ }^{44}$ Napominje da sve to piše "po nagovaranju preuzv. g. Ožegovića, koji moje misli dieli, a ujedno i za opravdanje proti kojekakvim mogućim klevetam. Ja žudim radje danas nego sutra u Hrvatsku, - al dajte mi i način bivstvovanja". ${ }^{45}$ Već pismom od 9. kolovoza je Kostrenčić zahvalio Strossmayeru na čestitkama zbog imenovanja na mjesto sveučilišnog knjižničara u Zagrebu. U tom kontekstu Kostrenčić piše da je bio u Zagrebu, i položio je prisegu, a smatra da će tamo glede posla u knjižnici biti “velikoga

${ }^{36}$ AHAZU, Kostrenčić - Strossmayer, br. 10. Pismo koje je I. Kostrenčić 9. V. 1875. (Beč) uputio J. J. Strossmayeru.

$37 \mathrm{Na}$ ist. mj.

${ }_{38} \mathrm{Na}$ ist. mj.

$39 \mathrm{Na}$ ist. mj.

$40 \mathrm{Na}$ ist. mj.

${ }^{41}$ Na ist. mj. Moguće je da se ovdje aludira na Dragutina Pogledića, koji je u vrijeme sklapanja Nagodbe bio predstojnik Odjela za bogoštovlje i nastavu pri Zemaljskoj vladi u Zagrebu (1869.-1871.), a potom i veliki župan Zagrebačke županije (1871.-1873., 1875.-1881.). Također, obnašao je i niz drugih dužnosti (povjerenik bana Jelačića za područje grada Varaždina i Varaždinske županije, podžupan Zagrebačke i Virovitičke županije, tajnik i savjetnik Namjesničkoga vijeća). O njemu usp. "Pogledić (Prigledić)", Hrvatska enciklopedija, sv. 8, Zagreb 2006., str. 561.

42 AHAZU, Kostrenčić - Strossmayer, br. 10. Pismo koje je I. Kostrenčić 9. V. 1875. (Beč) uputio J. J. Strossmayeru.

43 Na ist. mj.

$44 \mathrm{Na}$ ist. mj.

$45 \mathrm{Na}$ ist. mj. 
Ivica Zvonar: Korespondencija između Josipa Jurja Strossmayera i Ivana Kostrenčića...

Zb. Odsjeka povij. znan. Zavoda povij. druš. znan. Hrvat. akad. znan. umjet., 34 (2016), str. 197-211

okapanja, pošto ljudi neimaju ni volje, ni znanja". ${ }^{46} \mathrm{No}$, on se nada da će ustrajnim radom i pomoću onih koji ga podupiru, poput Strossmayera, uspjeti u radu. Također, zahvalio je Strossmayeru i radi "brige o moju buduću drugaricu", a pri tome se uzda i u pomoć prijatelja Paje Kolarića iz Osijeka. ${ }^{47}$ Napominje da bi bio sretan kad bi mogao dobiti za ženu osobu koju mu biskup preporučuje. Zahvaljuje u ovoj prigodi biskupu za poslanu "fotografiju od Vas ubijenoga vepra", te mu piše da će u to ime u njegovo zdravlje piti "kad dodjem 'auf Brautfahrt' (zaručnički / svadbeni put, op. I. Z.) u Djakovo" . ${ }^{48} \mathrm{Na}$ koncu, zahvaljuje Strossmayeru na svim dobročinstvima, i nada se da će mu se moći odužiti.

Iz Kostrenčićevih pisama Strossmayeru saznajemo ponešto i o njegovom radu na kulturnom i znanstvenom planu. Primjerice, Kostrenčić je 1871. u Zagrebu objavio zbirku pjesama Vrtić Frana Krste Frankopana, a dva je primjerka potom poslao Strossmayeru kao znak svojega poštovanja prema njemu. ${ }^{49}$ Tijekom ljetnoga odmora 1874. godine planirao je obići kvarnerske otoke i prikupiti "materijal za hrvatsko-čakavsku slovnicu, a možda nadjem gdjegod i koju starinu" ${ }^{50}$ Nakon dolaska u Zagreb na mjesto ravnatelja Kraljevske sveučilišne knjižnice, Kostrenčić se aktivno uključio u kulturni život te je 1877. godine postao tajnikom i blagajnikom Matice hrvatske, a sudjelovao je i u nizu drugih Matičinih projekata. Tako se u pismu od 25. studenog 1888. Kostrenčić iz Zagreba obraća Strossmayeru u ime odbora Matice hrvatske koji je odlučio izdati u 10.000 primjeraka izabrane pjesme pokojnog Petra Preradovića. Zbog toga se planira napisati i što cjelovitiji Preradovićev životopis, pa je Matica preko novina pozvala pokojnikove prijatelje da Odboru daju na uvid svoju korespondenciju s Preradovićem. Zato je i Kostrenčić pismom zamolio biskupa da mu ustupi na uvid pisma iz svoje dugogodišnje korespondencije s Preradovićem, a on mu jamči "da ta pisma neće ugledati nitko izmim mene, i da će se iz njih samo ono izpisati, što zasieca strogo u život i književnu radnju pokojnikovu". ${ }^{51}$

U korespondenciji između Kostrenčića i Strossmayera povremeno nailazimo na komentare političkih prilika u Austro-Ugarskoj Monarhiji, i razmišljanja o položaju slavenskih naroda. Tako Kostrenčić u vrlo opširnom pismu od 22. studenoga 1871., napisanom na četiri velike stranice, upućenom vjerojatno iz Beča, piše Strossmayeru o političkim prilikama u Beču - npr. izvještava ga o Beustovu odstupu i držanje

46 AHAZU, Kostrenčić - Strossmayer, br. 12. Pismo koje je I. Kostrenčić 9. VIII. 1875. (Beč) uputio J. J. Strossmayeru.

47 Na ist. mj.

$48 \mathrm{Na}$ ist. mj.

49 AHAZU, Kostrenčić - Strossmayer, br. 1. Pismo koje je I. Kostrenčić 22. V. 1871. (Beč) uputio J. J. Strossmayeru. Glede Kostrenčićeva rada oko pronalaska i tiskanja pjesama Frana Krste Frankopana za detaljniji uvid potrebno je pogledati njegovu korespondenciju s Franjom Račkim. Usp. Arhiv Hrvatske akademije znanosti i umjetnosti, fond: Ostavština Franje Račkog, Pisma Ivana Kostrenčića upućena Franji Račkome, Sign.: XII, A 317/ br. 1-52. Osobito usp. pisma br. 17, 19, 20, 22-25, 27, 32, 35, 45.

50 AHAZU, Kostrenčić - Strossmayer, br. 9. Pismo koje je I. Kostrenčić 28. VII. 1874. (Beč) uputio J. J. Strossmayeru.

51 AHAZU, Kostrenčić - Strossmayer, br. 14. Pismo koje je I. Kostrenčić 25. XI. 1888. (Zagreb) uputio J. J. Strossmayeru. 
Ivica Zvonar: Korespondencija između Josipa Jurja Strossmayera i Ivana Kostrenčića... Zb. Odsjeka povij. znan. Zavoda povij. druš. znan. Hrvat. akad. znan. umjet., 34 (2016), str. 197-211

cara u tim zbivanjima; vrlo oštrom stavu cara o ustanku u listopadu 1871. u Rakovici; o politici i programu Gyule Andrássya i Karla Auersperga, te o situaciji kod Poljaka i Čeha, kao i o radu pojedinih hrvatskih političara iz Dalmacije (npr. Stjepan Mitrov Ljubiša, Rafo Arneri, Vice Vuletić, Ivan Danilo i drugi). Također, Kostrenčić izvještava Strossmayera o pisanju tiska u pojedinim pitanjima, posebice o odnosu Hrvata i Mađara, pa u tom smislu kratko spominje razgovore Melchiora Lónyaya i Lazara Hellenbacha s Matijom Mrazovićem i Petrom Preradovićem, uz napomenu da će mu o tome sam Preradović pisati. ${ }^{52}$ Kostrenčić u pismu upućenom 9. kolovoza 1875. iz Beča piše biskupu Strossmayeru o srbijanskom knezu Milanu Obrenoviću, do kojega nije uspio doći i prenijeti mu biskupovu poruku, te o prilikama u Srbiji. Tom prigodom, piše mu i o slanju oružja od strane pojedinih Dalmatinaca koji sudjeluju u akcijama potpore ustanicima u Hercegovini. ${ }^{53}$ Također, kratki komentar političke situacije u Srbiji donosi Kostrenčić i u pismu od 16. kolovoza $1875 .{ }^{54}$ Među ostalim, Kostrenčić je u svojim pismima Strossmayeru komentirao i zbivanja na crkvenom planu, posebice događanja oko izbora nasljednika senjsko-modruškog biskupa Venceslava Soića. ${ }^{55}$

\section{Zaključak}

Korespondencija između biskupa Josipa Jurja Strossmayera i istaknutog hrvatskog sveučilišnog knjižničara i kulturnog djelatnika Ivana Kostrenčića, koja se čuva u fondu "Ivan Kostrenčić, Korespondencija, Josip Juraj Strossmayer", odnosno u fondu "Korespondencija, Pisma Strossmayeru, Ivan Kostrenčićc u Arhivu Hrvatske akademije znanosti i umjetnosti u Zagrebu, predstavlja izvor za uvid u određene aspekte njihovog kulturnog i političkog djelovanja u bremenitim razdobljima hrvatske povijesti druge polovine 19. stoljeća. Također, njihova pisma nam otkrivaju, doduše samo fragmentarno, i manje poznate događaje dijelom vezane za privatnu sferu i profesionalnu aktivnost.

U vrijeme rada u Dvorskoj knjižnici u Beču (1868.-1875.) Kostrenčić je održavao intenzivne kontakte s članovima tamošnje "hrvatske kolonije". Često puta je prenosio Strossmayerove pozdrave, poruke i pisma njegovim prijateljima i suradnicima $u$ Beču - npr. M. Ožegoviću, P. Preradoviću, F. Miklošiću, J. Jirečeku, M. Pavlinoviću, M. Klaiću, L. Montiju, i drugima, te prosljeđivao njihove odgovore biskupu. Osobitu bliskost, veliko međusobno povjerenje i suradnju Kostrenčić je ostvario s obitelji Ožegović i biskupom Strossmayerom, kao i s obitelji Preradović. Možemo reći da je

52 AHAZU, Kostrenčić - Strossmayer, br. 2. Pismo koje je I. Kostrenčić 22. XI. 1871. (Beč?) uputio J. J. Strossmayeru.

53 AHAZU, Kostrenčić - Strossmayer, br. 12. Pismo koje je I. Kostrenčić 9. VIII. 1875. (Beč) uputio J. J. Strossmayeru.

54 AHAZU, Kostrenčić - Strossmayer, br. 13. Pismo koje je I. Kostrenčić 16. VIII. 1875. (Beč) uputio J. J. Strossmayeru.

55 AHAZU, Kostrenčić - Strossmayer, br. 11. Pismo koje je I. Kostrenčić 28. VI. 1875. (Beč) uputio J. J. Strossmayeru. 
Ivica Zvonar: Korespondencija između Josipa Jurja Strossmayera i Ivana Kostrenčića...

Zb. Odsjeka povij. znan. Zavoda povij. druš. znan. Hrvat. akad. znan. umjet., 34 (2016), str. 197-211

na određeni način tijekom svojega 'bečkog razdoblja' on sve njih povezivao - posjećivao ih i družio se njima, te im mnogo puta bio na usluzi u obavljanju niza poslova i pri ostvarivanju kontakata. Primjerice, Kostrenčić je tako prema Strossmayerovim nalozima provjeravao u arhivima, ministarstvima i drugim tijelima podatke, i slao biskupu izvatke iz određenih dokumenata, kupovao i preuzimao umjetnine i predmete, brinuo se za restauraciji ili pak izradu okvira i stakala na slikama, te vodio brigu o njihovom transportu u Hrvatsku. U tom kontekstu vodio je i brigu glede dijela poslova u svezi uređenja katedrale u Đakovu. Osim toga, Kostrenčić je prema Strossmayerovim naputcima posjećivao i konzultirao slikare, restauratore, procjenitelje i poznavatelje umjetničkih djela, kako bi od njih dobio određene informacije, te im prenio Strossmayerove zahtjeve ili pak zastupao njegove interese. Povjerene poslove je obavljao, pažljivo, strpljivo i obzirno, nastojeći da trošak u konačnici bude povoljniji. U određenim je situacijama Kostrenčić, kako se vidi iz korespondencija, svoje slobodno vrijeme čak podređivao poslovima koje je obavljao za biskupa, a vidljivo jest da je on povremeno činio Strossmayeru i neke usluge privatne naravi. Zbog svega toga je Strossmayer cijenio Kostrenčićev rad, i bio mu je veoma zahvalan.

U korespondenciji između Kostrenčića i Strossmayera povremeno nailazimo na komentare političkih prilika u Austro-Ugarskoj Monarhiji, i razmišljanja o položaju slavenskih naroda. Pregledom njihove korespondencije razvidno je da se Strossmayer u svojim pismima osvrće na političke prilike u Austro-Ugarskoj Monarhiji, i na djelovanje dijela istaknutih hrvatskih političara iz razdoblja sedamdesetih godina 19. stoljeća (npr. Mirko Šuhaj, Matija Mrazović, Ivan Danilo, Đuro Vojnović i dr.). Zato u pismima nailazimo na Strossmayerove, ali i Kostrenčićeve kratke i britke komentare o političkim prilikama u Monarhiji nakon Nagodbe, kao i na kritičke opaske o djelovanju istaknutih austrijskih, mađarskih i hrvatskih političara toga vremena. 
Ivica Zvonar: Korespondencija između Josipa Jurja Strossmayera i Ivana Kostrenčića..

Zb. Odsjeka povij. znan. Zavoda povij. druš. znan. Hrvat. akad. znan. umjet., 34 (2016), str. 197-211

\section{Prilozi}

Prilog 1. Pismo koje je Ivan Kostrenčić uputio Josipu Jurju Strossmayeru 22. svibnja 1871. (br. 1)

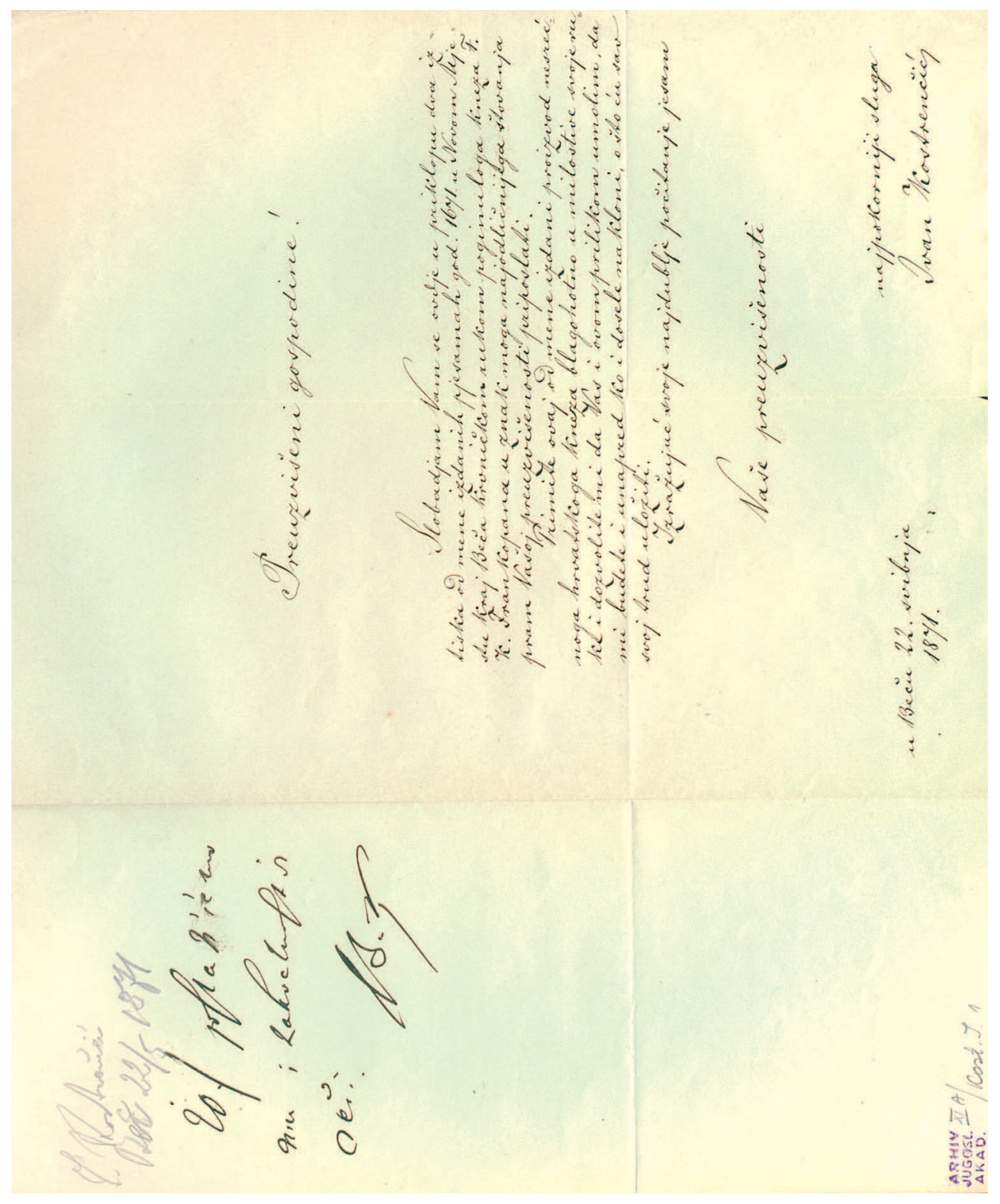


Ivica Zvonar: Korespondencija između Josipa Jurja Strossmayera i Ivana Kostrenčića...

Prilog 2. Pismo koje je Josip Juraj Strossmayer uputio Ivanu Kostrenčiću 15. rujna 1871. (br. 3)

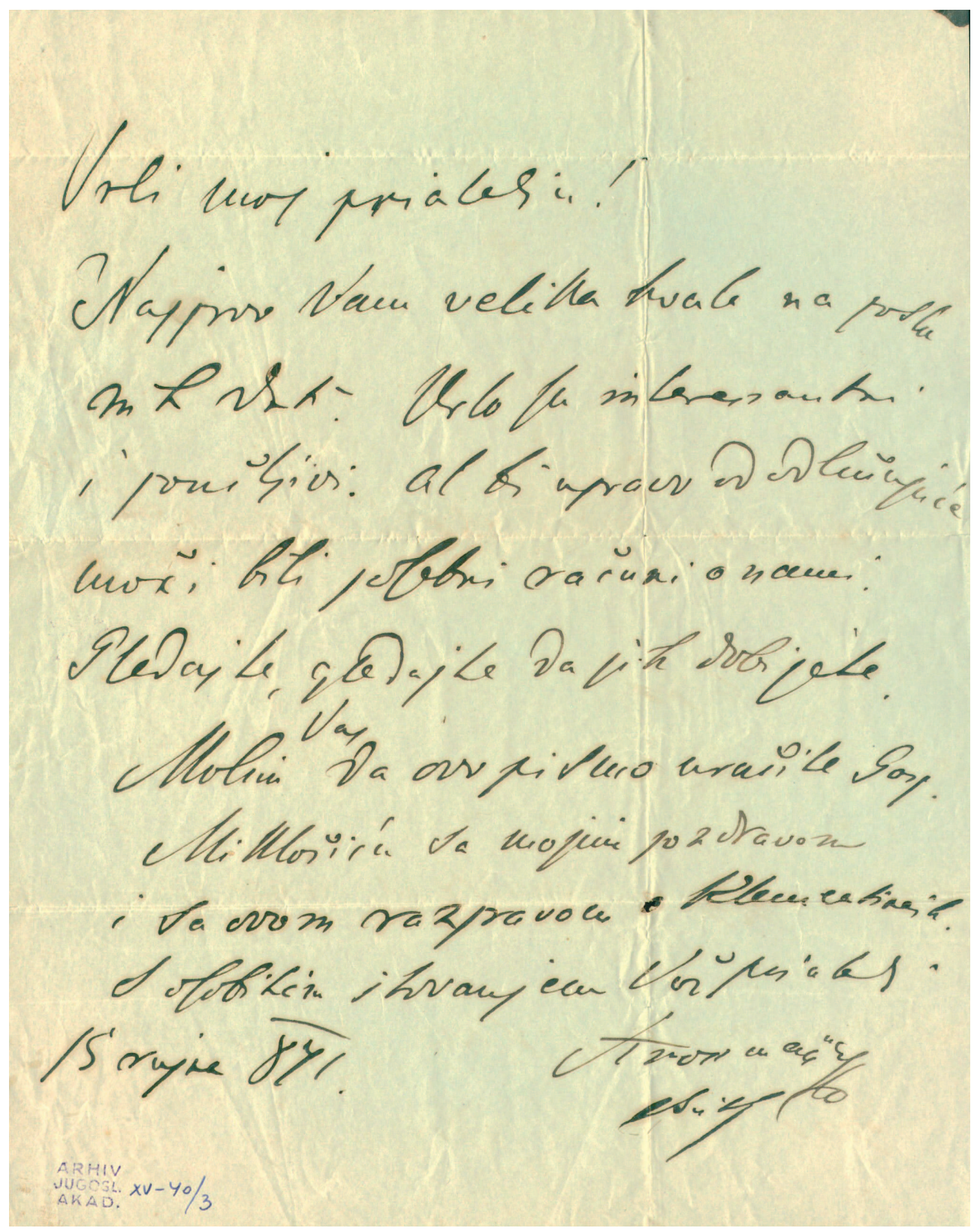


Ivica Zvonar: Korespondencija između Josipa Jurja Strossmayera i Ivana Kostrenčića...

Zb. Odsjeka povij. znan. Zavoda povij. druš. znan. Hrvat. akad. znan. umjet., 34 (2016), str. 197-211

Ivica Zvonar

\title{
The Correspondence between Josip Juraj Strossmayer and Ivan Kostrenčić in the Archive of the Croatian Academy of Sciences and Arts
}

\author{
Summary
}

In the article, the author briefly presents the correspondence between Bishop Josip Juraj Strossmayer and the eminent Croatian cultural worker and Librarian of the University Library Ivan Kostrenčić, which is kept in the Archive of Croatian Academy of Sciences and Arts in Zagreb. In the series "Ivan Kostrenčić, Korespondencija, Josip Juraj Strossmayer" [Ivan Kostrenčić, Correspondence, Josip Juraj Strossmayer] are kept 16 letters and one note which Strossmayer directed to Kostrenčić from Đakovo between 1869 and 1899. Also, in the legacy of Strossmayer in the series "Correspondence, Letters to Strossmayer, Ivan Kostrenčić" there are 16 letters which Ivan Kostrenčić directed to Strossmayer between 1871 and 1888. Responding to Strossmayer's demands, Kostrenčić checked different data in archives, ministries and other bodies in Vienna for the bishop and his collaborators. Besides that, he sent excerpts from particular documents to the bishop, bought and received works of art and other objects, took care of their restoration, and so on. In the correspondence, commentaries on political circumstances in the Austro-Hungarian Monarchy and reflections on the position of Croats and citizens of other Slavic nations may also occasionally be found. As a historical source, these letters provide an insight into particular aspects of the cultural and political agency of Strossmayer and Kostrenčić in the fraught periods of Croatian cultural and political history of the second half of the nineteenth century.

Key words: Josip Juraj Strossmayer, Ivan Kostrenčić, correspondence, Croatian history, the nineteenth century, political history, cultural history 